UDC 339

DOI 10.33111/iep.2018.29.02_eng

\title{
Creation Of The Global Investment Process
}

\section{MyKola BURMAKA ${ }^{1}$}

\begin{abstract}
This article is concerned with the study of the major premises and key factors for creation of the global investment process within the frameworks of scientific and technological progress, primarily the digital and network transformation of economic activity. Methodological approaches to the characteristics of creative investments as a specific symbiosis of financial innovations and tools of creative management in the paradigm of the global economy were developed. The current mega-trends of the development of the global investment market were analyzed taking into account the variety of trends of geopolitical, geo-economic, science and technology and other factors. A reference of the modern processes of the creation of the global investment business that is focused on new global projects of innovative and technological nature and commercialization of intellectual and creative human resources in the post-crisis period was provided. The emphasis is upon the increase in investment activity in the field of financial technologies (fintech), a global financial and technological start-up that significantly transforms the established architecture of the global market for financial and investment services and configures a new ecosystem with a leading role of IT companies. The creative investment management with features of an interdisciplinary scientific nature was identified as a separate subsector in the methodological format of creative management. The empirical model of modern transformations of the global investment process was developed on the basis of a single innovative and technological context. The priority of technological and service components of the creation process of the global investment business was reasoned, and the motivational factors for modifying investment strategies in the conditions of increasing global market competition, as well as uncertainty and turbulence factors were determined. The system view on the global technologization of the financial and investment business was reviewed using the achievements of scientific and technological progress, new financial technologies and robotics of various processes and services for investors. The key determinants of the development of the global investment market were determined: innovatization, digitalization, networking, financial technologization and robotics. The need for further study of the formation of a new segment of the creative economy, the economy of artificial intelligence (robot economy) and contradictions of the creation of the global investment market associated with the emergence of crypto-assets, was justified.
\end{abstract}

KEYWORDS. Global economy, creative economy, creative investments, creative management, digital economy, network economy, investment strategies, financial innovations, financial technologies, technology companies, artificial intelligence, crypto-assets.

\section{Introduction}

The dominant trend of the modern economic development in the conditions of active formation of the economy and society of the future is the constant generation and use of creative resources, including

\footnotetext{
* This article was translated from its original in Ukrainian

${ }^{1}$ Mykola Burmaka - Candidate of Economic Sciences, professor, Honored Economist of Ukraine, external $\mathrm{PhD}$ candidate at the Department of International Economics, professor of the Department of International Management SHEE «Kyiv National Economic University named after Vadym Hetman». Sphere of scientific interest: corporate management, international financial market, stock market regulation, investment activities, global economy. E-mail: nburmaka@ukr.net
}

IEP, № 29, (2018) pp. 34-49

(C) Mykola Burmaka, 2018 «All rights reserved»

ISSN 1811-9832/2018/№ 2 (29) 
investment ones, based on new knowledge and innovations. The transformation of the established approaches and the development of existing investment theories are primarily due to the processes of economic globalization and the crystallization of creative factors of sustainable development.

Considering the up to date creative format of investment activity, polyvariety of scientific interpretations and constant valorization of the related concepts, we can state mainly the creative apriori nature of the functioning of the modern investment industry. The intellectual and creative genesis of the investment process, as well as the permanent change in the relation between the material and the virtual in the global investment space in favor of the latter determines the dynamic behavior of trivial approaches to the standard classifications of investments with a shift from the limited material resources of development to virtually unlimited non-material primarily intellectual and innovative human resources.

With advent of creative industries, creative enterprises and products, economic science records the emergence of new semantic signs of the creation of investments and the investment business. In modern scientific research, a significant role in these processes is assigned to competition that induces the company to constantly balance between profitability and risk and constantly analyze and take into account internal and external factors influencing its activities ${ }^{2}$.

In the $20^{\text {th }}$ century, economic globalization is a key factor and environment for creation of the investment process, when the current models of corporate, banking and investment capital movement are implemented using the latest achievements in information technology, digitalization and networking.

The innovative (creative) component in the formation of valid methods of instrumental, composite and technological nature in solving various problems of investment is thoroughly considered in the works of the founders of financing engineering as a separate scientific field: D.F. Marshall and V.K. Bansal, L. Galits ${ }^{3}$, K. Zopunidis, M. Dumpus and P.M. Pardalos ${ }^{4}$, Z. Bodi, A. Kein and J.A. Markus ${ }^{5}$.

The applied aspects of the investment process in the activities of companies are described, in particular, by S. Ross ${ }^{6}$, F. Myshkin ${ }^{7}$,

\footnotetext{
${ }^{2}$ Marshal, D., Bansal V. Financial Engineering: The Complete Guide to Financial Innovations. Moscow: INFRA-M (1998): 49. [In Russian].

${ }_{4}^{3}$ Galits, L. Financial engineering: tools and ways to manage financial risk: Moscow: TVP, 1998. [In Russian].

${ }_{5}^{4}$ Zopounidis, C., Doumpos M. and Pardalos P.M. Handbook of Financial Engineering. 2008

${ }_{6}^{5}$ Body, Z, A. Kein, and A. Markus. Investment Principles. Moscow: Williams, 2002. [In Russian].

${ }^{6}$ Ross, S. Principles of corporate finance. The key to the success of a commercial organization - financial planning and management. Edited by Yu. Shlenov. Moscow, 2001. [In Russian]..

${ }^{7}$ Mishkin, F.S. The Economics of Money, Banking and Financial Markets. Kyiv: Basis, 1998. [In Ukrainian].
} 
I. Blank ${ }^{8}$, L. Cheng and J. Finnerti ${ }^{9}$, who focused on innovative methods of the company's appreciation primarily by using new financial tools and schemes together with the improved models of its production or strategic activities.

Certain issues of the transformation of intellectual capital into original investment decisions, as well as the priority of intellectualization and individualization in implementation of investment activities in the conditions of financial globalization are covered by S. Vayn ${ }^{10}$, V. Tvardovsky and S. Parshykov ${ }^{11}$, K. Richards ${ }^{12}$ and B. Stinbardzher ${ }^{13}$. The framework of studies of the influence of the creation on the formation of the global investment space in the context of the digital, network and information economy development is laid, in particular, in the scientific revisions of D. Lukianenko, O. Doroshenko and T. Galakhova ${ }^{14}$, F. Webster ${ }^{15}$, A. Gritsenko ${ }^{16}$, A. Maslov ${ }^{17}$, O. Lukianenko $^{18}$, Dzh.Khokins ${ }^{19}$ and N.A. Navrotskaia ${ }^{20}$.

The creative economy in the methodological format of the global economy can be considered as complementary in nature and similar in structure and subjectivity together with a network, digital and information economy ${ }^{21}$.

The UNCTAD World Investment Report of 2017 on Investments and the Digital Economy states that «the digital economy is one of the main engines of growth and development and is important for investments,

\footnotetext{
${ }^{8}$ Blank, I. A. Investment Management: Training course. Kyiv: N-Center, 2001. [In Russian].

${ }^{9}$ Cheng Lee, Finnerty J. Corporate Finance: Theory, Methods, and Practice. Moscow, 2000. [In Russian].

${ }^{10}$ Vayn, S. Investments and trading: Formation of an individual approach to making investment decisions. Moscow: Alpina Business Books, 2006. [In Russian].

${ }^{11}$ Tvardovsky, V., Parshikov S. Secrets of stock trading: Stock trading on stock exchanges. Moscow: Alpina Business Books, 2005. [In Russian].

${ }_{12}$ Richards, K. Psychology of investment. How to stop doing stupid things with your money, Moscow: MIF, 2013. [In Russian].

${ }_{13}$ Steenbarger, B. Psychology of trading. Tools and methods for decision making. Moscow: Alpina Publisher, 2018. [In Russian].

${ }_{14}$ Lukianenko, D., O. Doroshenko, T. Galakhova, et al. The paradigm of creative management in the global economy: monographs. Edited by Doctor of Economics, prof. Lukianenko D. Kyiv: KNEU (2016): 124-126. [In Ukrainian].

${ }_{15}^{15}$ Webster F. Theories of the Information Society. Moscow: Aspect Press, 2004. [In Russian].

16 Gritsenko, A., T. Artyomova, A. Gritsenko, T. Krichevskaya, et al. Hierarchy and networks in the institutional architectonics of economic systems: monograph. Edited by Gritsenko A. Kyiv: NAS of Ukraine, Institute of Economics. and forecasting, 2013. [In Ukrainian].

${ }^{17}$ Maslov, A. «The genesis of the theory of information economics and her place in modern economic thought». Actual problems of economics 117 (2011): 13-23. [In Ukrainian].

Maslov, A. «Stages of the development of the information economy theory in the second half of XX at the beginning of the XXI centuries. Bulletin of the Taras Shevchenko National University of Kyiv. 128 (2011): 11-15. [In Ukrainian].

${ }^{18}$ Lukianenko, O. Innovative factors of global competitiveness: monographs. Kyiv: KNEU, 2015. [In Ukrainian].

${ }^{19}$ Hawkins, J. Creative Economy. How to turn ideas into money. Moscow: Classic-XXI century, 2011. [In Russian].

${ }^{20}$ Navrotska, N. Globalization of investment process: monograph. Donetsk: Lira, 2014. [In Ukainian].

${ }^{21}$ Lukianenko, D, A. Poruchnik, and T. Kalchenko, et al. Global economics. Tutorial. Kyiv: KNEU, 2017: 28, 29, 32. [In Ukrainian].
} 
and investments in its turn are extremely important for digital development. Digitization can radically change the nature of international activities of multinational enterprises and the influence of foreign branches on host countries. $\gg^{22}$ At the same time, the intellectual capital forms the basis of the creative economy and related specific sectors of the global economy, focused on achieving market goals with the help of creative human potential.

Analyzing the current scientific concepts of the creation of economic processes, we can recognize the special relevance of the problem of the influence of creative methods and approaches on the success of investment business as a factor in sustainable economic growth, which requires further search for the proper methodology and tools for the study of these phenomena.

It is important to note that the creative economy motivates the formation of new contours and structures of the global investment space penetrating almost all fields of the globally-computerized society. The latest trends in the transformation of the investment industry under the influence of financial innovation and intellectualization require further scientific understanding.

The purpose of the article is to identify the objective prerequisites and factors for the creation of investment activity in the global economic environment, the growing diffusion of creative financial tools and technologies in the investment industry, and the formation of the methodological foundations for the study of global creative processes hereon.

\section{Key Factors in the Creation of the Modern Investment Processes}

Today, formation and use of creative resources is one of the key imperatives of the global economic development. Global investment entropy determines the creation processes of investment business, which are based on the innovative and intellectual nature of creative investments. The essential characteristic of such investments is based on the synergy of financial and technological tools ${ }^{23}$, which in its turn leads to the formation of a global holistic ecosystem providing a wide range of financial and investment services.

Using the traditional approaches to the classification of investments and taking into account the dualistic nature of creative investments, it

\footnotetext{
${ }^{22}$ World Investment Report 2017. Investment and the digital economy. Key trends and overview. UNCTAD 2017 (Overview). http: //unctad.org/en/PublicationsLibrary/wir_2017_overview_ru.pdf.

Lukianenko, D., M. Burmaka, T. Galakhova. "Identification of Creative Investments in the Global Economy». International Economic Policy, no. 25 (2016): 7-20. [In Ukrainian].
} 
can be said that creative investment is a «unique» product of the financial innovation (financial engineering) aimed at achieving various investment goals on the one hand, and, on the other, a set of interrelated means of financial, technological and motivational nature, which are determined by the economy type (traditional, postindustrial, creative or combined), composition of creative implementation tools (virtual, intellectual, organizational, institutional or regulatory), as well as qualitative and quantitative characteristics of the investment environment (informatization, digitalization, networking, robotics). The motivational aspects of the creation of the modern investment process are stipulated primarily by regulatory, tax and administrative factors clearly manifested during the financial crisis and market turbulence.

In creative industries investments and industries of the economy can be considered as creative according to industry, while innovative financial tools and technologies can serve both creative and traditional sectors of the economy. The relevant combination of these approaches significantly enhances the functional orientation of creative investments, adapting them to the needs of the creative economy development at most.

These features of the creative investment and explication of the phenomenon of the creation of the global investment process can solve the actual problem of transformation of the intellectual capital into the investment capital by commercializing innovations and forming on this basis a global market for financial innovations that operates in parallel with the global market for creative investments.

Highlighting the creative investments in the methodological format of investment classification, we note that they appear as an important component of investment activity based on the methodology and tools of the creative management ${ }^{24}$. The discursive extension of the creative management approaches to the investment business, as well as the use of innovative and intellectual technologies for making investment decisions form a specific subsystem of creative management, the creative investment management, which acquires methodological figures of an interdisciplinary nature. The organic combination of traditional management of investment assets on the one hand, and creative and innovative mechanisms of production of investment business on the other hand, forms a specific symbiosis of finance, investment, information and digital technologies, intelligence and creativity in the modern paradigm of the global economy.

\footnotetext{
${ }^{24}$ Lukianenko, D., O. Doroshenko, T. Galakhova, et al. The paradigm of creative management in the global economy: monographs. Edited by Doctor of Economics, prof. Lukianenko D. Kyiv: KNEU (2016): 124-126. [In Ukrainian].
} 


\section{Table 1 Global Investment Market Dynamics}

(Total amounts, billion US dollars)

\begin{tabular}{|c|c|c|c|c|c|c|c|}
\hline & 2012 & 2013 & 2014 & 2015 & 2016 & 2017 & 2018 \\
\hline $\mathrm{FDI}^{25}$ & $1.330,0$ & $1.452,0$ & $1.228,0$ & $1.921,0$ & $1.868,0$ & $1.430,0$ & $\begin{array}{c}1.450-1.470 \\
\text { (forecast) }\end{array}$ \\
\hline $\begin{array}{l}\text { Venture capi- } \\
\text { tal invest- } \\
\text { ments }^{26}\end{array}$ & 45,3 & 52,0 & 93,3 & 136,2 & 110,0 & 164,4 & \\
\hline$M \& A^{27}$ & $3.330,0$ & $3.699,0$ & $4.812,0$ & $5.870,0$ & $4.893,0$ & $4.741,0$ & \\
\hline $\begin{array}{l}\text { Market value } \\
\text { of intangible } \\
\text { assets S\&P } \\
5_{000^{28}}\end{array}$ & 625,0 & 647,1 & 684,7 & 745,0 & 805,5 & 852,0 & $\begin{array}{c}940-950 \\
\text { (forecast) }\end{array}$ \\
\hline Fintech $^{29}$ & 8,9 & 15,1 & 43,2 & 62,5 & 42,3 & 38,2 & $\begin{array}{c}57,9 \\
\text { (first six } \\
\text { months) }\end{array}$ \\
\hline
\end{tabular}

Analysis of the main macroeconomic indicators of the global investment market, which are given in Table 1, determines a number of complex and symptomatic trends of its development during the last post-crisis years. Against the background of a significant three-year decline in FDI, the global venture capital investment market has been growing during this period.

The negative growth of the global FDI market was due to certain protectionist actions of the developed economies of the world (the increase in interest rates by Central Banks of the developed countries, the change in corporate configurations due to changes in the economic policies of a number of powerful sovereign players of the world market, the latest tax reforms in the developed countries, for example, in the USA), resulting in a reversal of the global FDI flows towards the developed countries and, as a consequence, some decrease in the volume of direct investments in developing countries $^{30}$. A similar pattern emerges on the global mergers and acquisitions market, while the indicator of cross-border trade of mergers and acquisitions decreased to a greater extent (by 23\%) than the overall indicator.

\footnotetext{
25 World Investment Report 2018. «Investment and New Industrial Policies». UNCTAD, 2018. https://unctad.org/en/PublicationLibrary/wir2018.en.pdf.

The 2017 Global CVC Report: PwC CB Insights (Money Tree Q4 2017). PwC / CB Insights, 2017. https://www.cbinsights.com/research/report/corporate-venture-capitaltrends-2017/

${ }_{28}$ According to the company Inventure Investment Group. https://inventure.com.ua/analities/investments

According to US Department of Commerce. Bureau of Economic Analysis; Table 1.5.5. https://www.bea.gov/system/files/2018-08/SNTables_0.pdf

Pulse of Fintech 2018. Global Analysis of Investment in Fintech. KPMG International, 31 July 2018. https://assets.kpmg.com/content/dam/kpmg/xx/pdf/ 2018/07/h1.

According to https://unctad.org/en/pages/newsdetails.aspx? OriginalVersionID $=1659$
} 
The decrease in global FDI flow, which contrasts with other positive macroeconomic trends, such as the growth of world GDP and world trade, is objectively determined by increased geopolitical risks and global political uncertainty, which will significantly determine the dynamics and volume of the further recovery of the global FDI in the short and mid-term.

As noted by a number of analysts and researchers, the record growth rate of the global venture capital market is primarily caused by the activity of Asian, American and Western European companies due to additional financing in the most dynamic areas of venture investment today like pharmacy and biotechnology, artificial intelligence development and machine learning. At the same time, it is necessary to take into account the obvious dependence of the «general state» of the venture capital market on the condition of the stock market and the stability of global stock indexes, which largely determine the dynamics of the IPO of high-tech companies supported by venture capital.

\section{Fintech Start-Ups as Drivers of the Creation of Financial and Investment Business}

Current trends of investment activity in the fintech field, the newest and rapidly growing area of the global economy, which are most clearly focused on the latest achievements of the science and technology progress, financial innovations, achievements and advantages of the information, digital, network and intellectual components of the global economy, require special consideration.

By its transcendent nature, fintech is a large-scale financial and technology start-up that is able to radically change the architectonics of the global market for financial and investment services in the near future and even to lead to the formation of a global alternative capital market. Thus, in a recent Study of the World Economic Forum devoted to fintech ${ }^{31}$, it is noted that financial and technology start-ups have significantly influenced the activities of traditional players of the financial and investment services market over the past two or three years and, most importantly, they have identified promising areas of their development, defined the format and the dynamics of innovation in key areas of the financial services market, achieved the stability of their business and high involvement in the global chains of the financial and investment process.

Experts believe that global technology corporations such as Facebook, Google, Amazon and Alibaba constitute a significant

\footnotetext{
${ }^{31}$ Beyond Fintech: A Pragmatic Assessment of Disruptive Potential in Financial Services. World Economic Forum, August 2017. https://www3.weforum.org/docs.
} 
competitive danger to transnational financial and investment companies and banks, the only countermeasure of which is the rapid adaptation of fintech technologies to their traditional activities, thus minimizing the negative effects of competition on the market of innovative financial services. In this context, the development of fintech as one of the methods for the creation of financial and investment processes confirms our thesis about the simultaneous functional orientation of the creation both on the established forms of the investment business and creative and innovative forms using creative investment tools, creative technologies and creative processing.

On the wave of the latest trends in global investments in the fintech field, they responded with a rapid growth in the first half of 2018, reaching 57.9 billion US dollars compared to 38.2 billion US dollars invested for 2017 (see Table 1).

The basis for reaching a new maximum was 9 mega-deals amounting to more than 1 billion US dollars, as well as a large-scale series of additional funding implemented by a number of promising Asian companies from China, Japan, India, Australia and Singapore ${ }^{32}$. At the same time, investment flows into the fintech industry were formed both in the form of FDI and through venture capital investments and mergers and acquisitions. Noteworthy is also the significant correlation between the growth rate of the fintech industry and the growth rate of the market value of intangible assets of the leading corporations included in the US stock index S\&P 500.

On the basis of the dynamics of the world investment market we considered and taking into account the current investment megatrends, we will identify a number of related trends that acquire global characteristics. These include the following: 1) the growing penetration of innovative technologies into the global financial and investment business, 2) global decentralization and deregulation of the financial and investment market, and 3) global competition for investment resources. These trends are organically interrelated, interdependent, mutually stimulate each other and require in-depth analysis.

According to experts, today the focus in the fintech field is on three high technologies that will become dominant in the near future in the development of the global market for financial and investment services: development of artificial intelligence, analysis of big data and cloud technologies. This leads to an increased interest of global investors (both venture and corporate) to expand their market presence of financial and technological projects in these areas, starting with various

\footnotetext{
${ }^{32}$ According to the materials https://stimul.online/articles/sreda
} 
rounds of initial and additional investment in innovation programs and ending with the entering venture capital companies to the IPO.

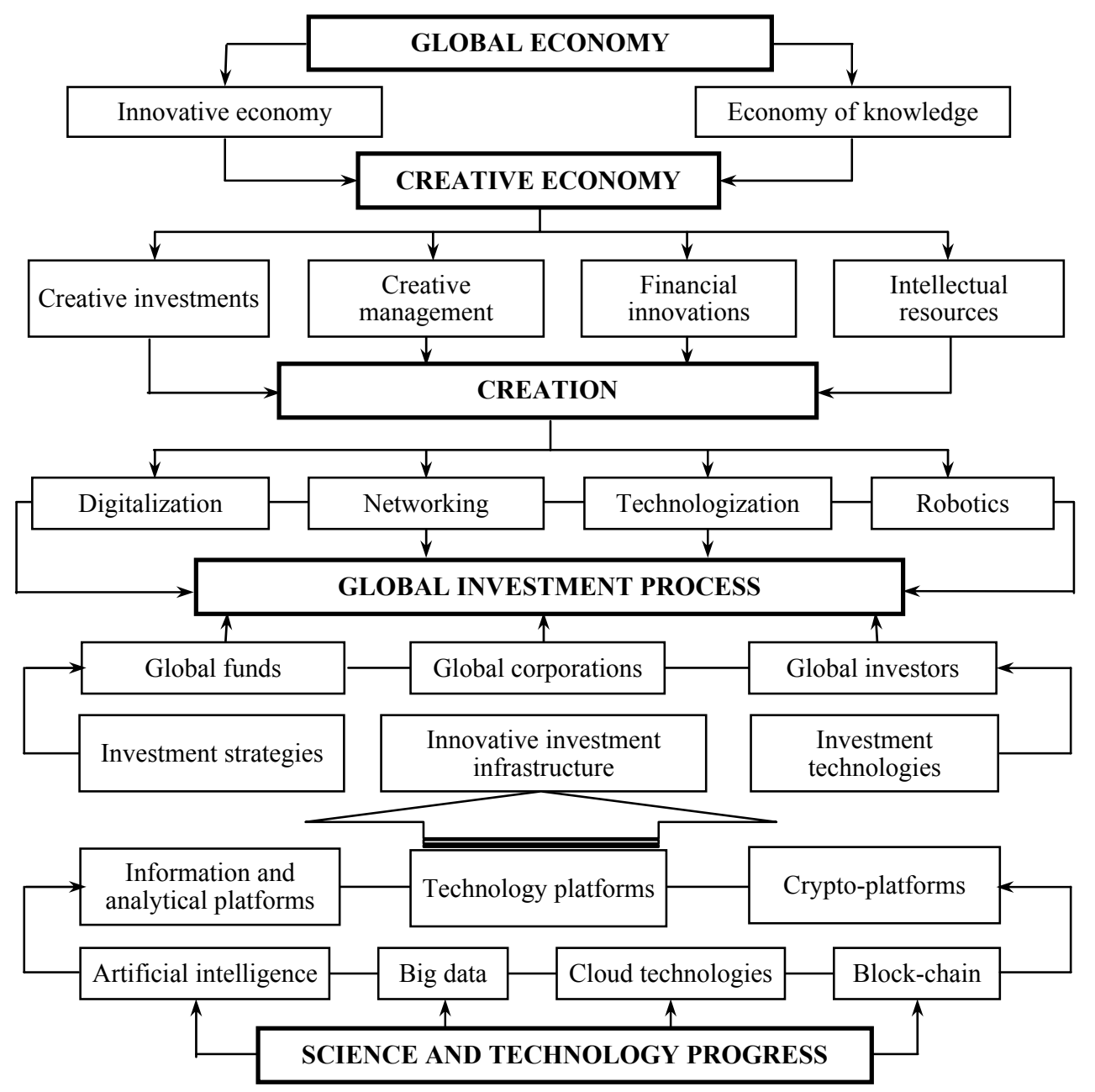

Fig. 1. Methodological format

for the creation of a global investment process

The expansion of just technological start-ups (IR technology, blockchain, information and analytical networks and platforms, algorithms and robotics) into the financial and investment industry leads to an irreversible transformation of the traditional model of the financial market and the formation on this basis of a new ecosystem determined by a number of interrelated factors like supply and demand, access 
channels to investment, innovation, technology, human creative potential and regulation. Technological innovations inevitably lead to the decentralization of the investment market, and its overregulation leads to the emergence of new, unregulated classes of investment assets based on the phenomenon of creation (Figure 1).

However, it would seem that the solution of some problems by investors, stimulated by their desire to avoid excessive regulation or to get rid of intermediation on financial and investment markets, maximally speeding up the operating speed of transactions, leads to the emergence of other equally complex and current issues, such as searching an adequate pricing system for new assets, the use of effective risk management methods when investing in these assets, the introduction of relevant mechanisms for «converting» and «linking» these assets to fiat (fiduciary) currencies. This complex of new issues is most clearly shown in the situation with advent of crypto-assets, which, in our opinion, becomes only the beginning of a rather contradictory stage of global changes in the very essence of money and a radical transformation of the financial market against the background of modern achievements of the science and technology progress.

\section{Empirical model of transformation of the global investment process}

Due to considerable amounts of investment capital that is today directed to growing financial and technological projects, as well as a steady increase in the number of financial centers and companies that seek to effectively use financial technologies for their growth, investments in the fintech industry have long-term positive prospects. The expansion of investment proposals has led to aggravation of competition for investments while increasing the cost of client capture and retention. This pushes the leading players of the global investment market to a deep differentiation and, as a result, the competition for a client begins to manifest itself not in the field of scaling the investment proposals, which requires fewer resources, but primarily in the field of greater personalization of investment needs of investors with a simultaneous desire to maintain or increase its market share.

That is, within the frameworks of the creation of the business investment process, there is a transition from the product (tool) orientation that has prevailed on the investment market for the last few decades to service orientation using big data to serve investors with almost all issues of their financial and investment activities.

Due to the fact that in the fintech field technology companies are beginning to have a more intensive impact on the development of the 
financial and investment market than traditional financial and credit and financial and investment institutions, the classical paradigm of financial engineering is undergoing gradual changes, in which innovative and creative financial instruments take a prominent place regardless of the technology of their use. Against the background of a rapid introduction of information, digital and network technologies in the investment business, it is the technological component that assumes the main content of financial engineering, often dictating financial and investment parameters for the development of a new financial tool.

This evolution of the classical financial engineering as an integral part of investment management is due, as noted above, to the creation of the investment process primarily due to modern innovative technologies, thanks to which near-instantaneous implementation of various investment, credit, payment, settlement, consulting and other operational solutions is achieved. Complex technologization of financial and investment services radically changes investors' understanding of the investment market opportunities and attracts more and more clients all over the world.

Today, conceptually new technologies are the dominant factor in the development of the global investment market, forming its strategic capabilities. Commoditization of financial and technological innovations causes a synergetic effect in the global economy, when financial institutions increasingly use modern technological developments in their activities and in contrast, technology companies realize their creative potential for development in the best way, primarily in the financial and investment field.

Today, the development of financial technologies objectively leads to the decomposition of this industry into a number of subsystems associated with various types of financial and investment activities (traditional, established and creative) but united by a single innovative technological context. For example, payments and settlements begin to be carried out for business models that use the block-chain or cryptocurrency technology, crediting based on analytical and information technology platforms, users of which are online creditors or online investors, investment management (capital) based on technology platforms and software that provide differentiated investment proposals to retail investors with quantitative and qualitative methods of stock market research (Figure 2).

In addition, for the so-called «personal finance» field, technology services are introduced to improve (optimize) the financial condition of retail clients, which allow them to control their expenses, savings, tax liability, as well as receive basic retail banking services outside the traditional bank. 


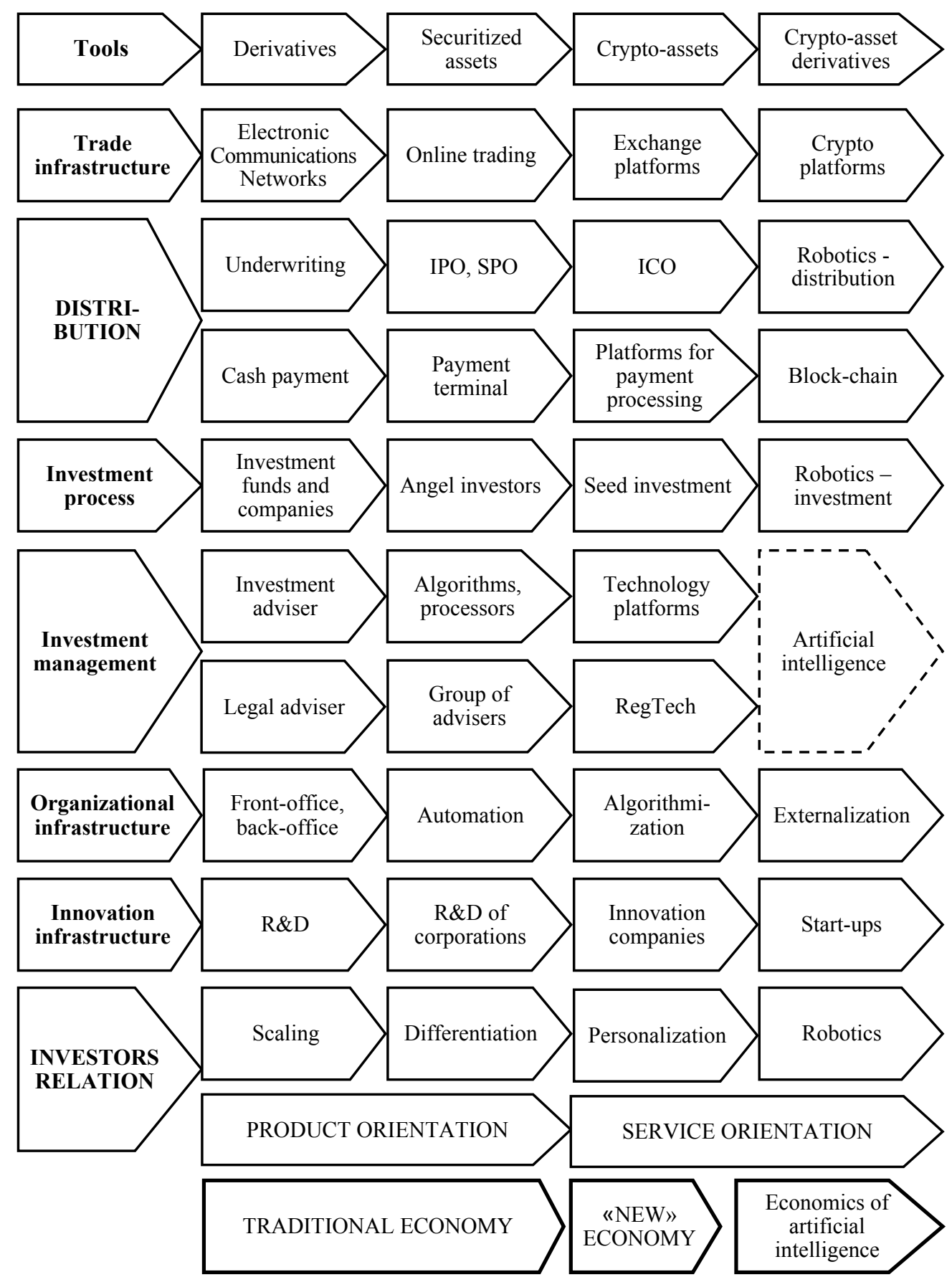

Fig. 2. Current transformational trends of the global investment process 
Deep differentiation of financial and investment needs of clients also causes the financial and technological specialization of companies that provide relevant services. In particular, companies specializing in insurtech «directly» develop new insurance technologies; regtech companies - technologies to facilitate compliance with regulations and rules in the conditions of legal «regionalization» of market regulation and the growing fragmentation of the regulatory environment, as well as protection against fraud of employees and clients; institutional fintech companies - a wide range of solutions and services that allow enterprises and financial institutions to algorithm and automate all financial and investment processes, ensure financial security, as well as to develop and implement strategies of institutional development.

Thus, the global technologization of economic activities increasingly influences the development of investment processes by pervasive informatization, digitalization, networking and robotics of traditional financial and investment services and business, causing the gradual formation of the creation- and technologically-based specific global investment ecosystem with a principally new market infrastructure, new members and new communications between them. The driving force of this process is the growing interest of investors in finding new creative investment proposals in a global environment, which can improve the efficiency of investment and significantly reduce the value chains of capital.

These opportunities are currently owned, first of all, by the growing financial and technological and investment and creative segments of the global economy, research and careful monitoring of transformation trends of which deserve the further attention of scientists and experts.

\section{Conclusion}

1. Today, the creation as a modern phenomenon of civilizational progress covers almost all areas of a globalizing society, causing a radical transformation of most sectors of financial and economic activities. Crystallization of creative, innovative and intellectual factors of sustainable economic development is most clearly manifested in the financial and investment business that in the post-crisis years shows rapid growth due to the formation of new investment priorities associated with the commercialization of intellectual and creative resources of society and the emergence of new and attractive investment objects of innovative and technological nature.

2. Creative methods and models significantly increase the efficiency of the investment business and motivate the formation of a fundamentally new architecture of the global investment space. The 
synergistic combination of traditional models of investment management with the latest financial technologies of investment activity form a specific symbiosis of creative management, creative investment, financial innovation, information, digital, network and cloud technologies and the human intellectual potential in the modern paradigm of the global economy. In these conditions, there is allocation of a separate subsystem, the creative investment management, in the methodological format of the creative management, which acquires the features of an interdisciplinary scientific nature.

3. New global trends are emerging that become dominant and decisive within the meaning of the prospects for the development of the global investment market: 1) growing penetration of new financial technologies into this market, 2) global market deregulation and decentralization under the influence of digitalization and networking of economic activity, and 3) improvement of global competition for investment resources and investors. Against the background of these trends, there is an expansion of the innovative and technological component of the investment business and the formation of the contours of a new global ecosystem of financial and investment services in the global economy.

4. The creation processes of investment business are characterized by the rapid growth of the role of global technology companies on the financial markets, which today constitute a serious competition to traditional transnational financial institutions. Financial and technological start-ups are beginning to play a leading role in the functioning of a wide range of modern investment and financial businesses, taking the main mission of financial engineering, which now is to generate such creative financial instruments that are most suitable for use in the global digital and network space. In order to achieve strategic parity in this competition, traditional financial institutions have to quickly introduce the latest financial technologies into their operations.

These processes are powered by several driving mechanisms, namely: innovations and modern developments in the field of artificial intelligence, analysis of big data and cloud technologies at the level of science and technology progress; digitalization, networking, block-chain technologies, cyber- and crypto-technologies at the level of the technology investment business; automation, algorithmization, externalization and robotics of various processes and services for clients and investors at the level of operating activities of financial and investment institutions.

5. The use of some elements of artificial intelligence and robotics mechanisms at various stages of the investment process leads to the formation of the contours of a certain segment of the creative economy, 
the robot-economy, in which the most complex investment strategies are implemented based on big data of financial, political, regulatory, legal, instrumental and organizational nature.

The growing interest of investors, both venture and corporate, in investing in the creative financial and investment segment of the global economy is due to the desire to improve the efficiency of their investment activities and significantly reduce the chain of formation of a new capital value. For this purpose, the global players of the investment market form an adequate market technological infrastructure focused on the provision of various services and deep personalization of clients' requests.

6. Today, financial technologies (fintech) are one of the most promising areas of development of the financial and investment segment of the global economy and at the same time they are the main driver of the creation of the global investment process. However, against the background of the positive trends in the development of the fintech industry, in recent years we have been observing complex and contradictory processes associated with the emergence of a new class of creative assets, the so-called crypto-assets. Today, the attention of a wide range of global investors, international and national regulators, as well as the general public of experts and specialists is focused on solving the problems of legitimizing crypto-assets in the global investment environment.

\section{References}

1. Beyond Fintech: A Pragmatic Assessment of Disruptive Potential in Financial Services. World Economic Forum, August 2017. https: / / www3.weforum.org/docs.

2. Blank, I. A. Investment Management: Training course. Kyiv: N-Center, 2001. [In Russian].

3. Body, Z, A. Kein, and A. Markus. Investment Principles. Moscow: Williams, 2002. [In Russian].

4. Cheng Lee, Finnerty J. Corporate Finance: Theory, Methods, and Practice. Moscow, 2000. [In Russian].

5. Galits, L. Financial engineering: tools and ways to manage financial risk: Moscow: TVP, 1998. [In Russian].

6. Gritsenko, A., T. Artyomova, A. Gritsenko, T. Krichevskaya, et al. Hierarchy and networks in the institutional architectonics of economic systems: monograph. Edited by Gritsenko A. Kyiv: NAS of Ukraine, Institute of Economics. and forecasting, 2013. [In Ukrainian].

7. Hawkins, J. Creative Economy. How to turn ideas into money. Moscow: Classic-XXI century, 2011. [In Russian].

8. Lukianenko, D, A. Poruchnik, and T. Kalchenko, et al. Global economics. Tutorial. Kyiv: KNEU, 2017: 28, 29, 32. [In Ukrainian]. 
9. Lukianenko, D., M. Burmaka, T. Galakhova. «Identification of Creative Investments in the Global Economy». International Economic Policy, no. 25 (2016): 7-20. [In Ukrainian].

10. Lukianenko, D., O. Doroshenko, T. Galakhova, et al. The paradigm of creative management in the global economy: monographs. Edited by Doctor of Economics, prof. Lukianenko D. Kyiv: KNEU (2016): 124-126. [In Ukrainian].

11. Lukianenko, O. Innovative factors of global competitiveness: monographs. Kyiv: KNEU, 2015. [In Ukrainian].

12. Marshal, D., Bansal V. Financial Engineering: The Complete Guide to Financial Innovations. Moscow: INFRA-M (1998): 49. [In Russian].

13. Maslov, A. «The genesis of the theory of information economics and her place in modern economic thought». Actual problems of economics 117 (2011): 1323. [In Ukrainian].

14. Maslov, A. «Stages of the development of the information economy theory in the second half of XX at the beginning of the XXI centuries. Bulletin of the Taras Shevchenko National University of Kyiv. 128 (2011): 11-15. [In Ukrainian].

15. Mishkin, F.S. The Economics of Money, Banking and Financial Markets. Kyiv: Basis, 1998. [In Ukrainian].

16. Navrotska, N. Globalization of investment process: monograph. Donetsk: Lira, 2014. [In Ukainian].

17. Pulse of Fintech 2018. Global Analysis of Investment in Fintech. KPMG International, 31 July 2018. https://assets.kpmg.com/content/dam/ $\mathrm{kpmg} / \mathrm{xx} / \mathrm{pdf} / 2018 / 07 / \mathrm{h} 1$.

18. Richards, K. Psychology of investment. How to stop doing stupid things with your money, Moscow: MIF, 2013. [In Russian].

19. Ross, S. Principles of corporate finance. The key to the success of a commercial organization - financial planning and management. Edited by $\mathrm{Yu}$. Shlenov. Moscow, 2001. [In Russian].

20. Steenbarger, B. Psychology of trading. Tools and methods for decision making. Moscow: Alpina Publisher, 2018. [In Russian].

21. The 2017 Global CVC Report. PwC/CB Insights, 2017. https:// www.cbinsights.com/research/report/corporate -venture-capital-trends-2017.

22. Tvardovsky, V., Parshikov S. Secrets of stock trading: Stock trading on stock exchanges. Moscow: Alpina Business Books, 2005. [In Russian].

23. Vayn, S. Investments and trading: Formation of an individual approach to making investment decisions. Moscow: Alpina Business Books, 2006. [In Russian].

24. Webster F. Theories of the Information Society. Moscow: Aspect Press, 2004. [In Russian].

25. World Investment Report 2017. Investment and the digital economy. Key trends and overview. UNCTAD 2017 (Overview). http: / / unctad.org/en/PublicationsLibrary/wir_2017_overview_ru.pdf.

26. World Investment Report 2018. «Investment and New Indūstrial Policies». UNCTAD, 2018. https: / / unctad.org / en / PublicationLibrary / wir2018.en.pdf.

27. Zopounidis, C., Doumpos M. and Pardalos P.M. Handbook of Financial Engineering. 2008.

The article was received by the editorial board on 18.10.2018. 